\title{
MOTIVATIONAL STRATEGIES IN TEACHING ENGLISH AS FOREIGN LANGUAGE: A CASE STUDY IN JUNIOR HIGH SCHOOL 7 KUNINGAN
}

\author{
Muhammad Aprianto Budie Nugroho \\ Department of English Education, the University of Kuningan, Indonesia. \\ E-mail: muh.apriantobn@gmail.com \\ Nining Mayda \\ Department of English Education, the University of Kuningan, Indonesia. \\ E-mail: maydaning92@gmail.com
}

APA Citation: Nugroho, M. A. B., \& Mayda, N. (2015). An analysis of motivational strategies in teaching English as foreign language: A case study in junior high school 7 Kuningan. English Review: Journal of English Education, 4(1), 82-93

Received: 06-01-2015

Accepted: 07-03-2015

Published: 01-12-2015

\begin{abstract}
:
This research aims to analyze motivational strategies in teaching English as foreign language at $7^{\text {th }}$ grade of Junior High School 7 Kuningan and to analyze students' attitudes towards motivational strategies that were applied by teachers in teaching EFL. The researchers used qualitative research by using classroom observation, interview, and questionnaires. The result taken from classroom observation and interview show teacher 1 and teacher 3 applied motivational strategies completely based on the phases of motivational strategies. Thus, the students responded these strategies positively. On the other hand, teacher 2 applied motivational strategies incompletely because the teacher missed the first phases. This was responded negatively by students. Therefore, the students were actively involved in teaching and learning process conducted by teacher 1 and teacher 2 , but the students were passively involved in teaching and learning process conducted by teacher 2. Furthermore, the result taken from questionnaires shows that students gave positive attitudes towards the teacher $1(88.25 \%)$, teacher $2(79.02 \%)$, and teacher $3(85.71 \%)$. Based on the findings, it can be concluded that the way the teachers applied motivational strategies in teaching EFL determined students' attitudes towards motivational strategies applied by teachers in teaching EFL.

Keywords: motivational strategies, phases of motivational strategies, students attitudes, teaching EFL
\end{abstract}

\section{INTRODUCTION}

In the world, English as an international language has been used by many people and become the lingua franca for communication, business, education, and opportunity. (Latha and Ramesh, 2012). In Indonesia, it is first foreign language and has been studied in secondary schools for long time (Nugroho, 2008). It has been introduced starting from kindergarten up to university level. However, for Indonesian students who learn English as a foreign language, English is still difficult to learn and quality of language learning itself is often low.

There are some factors affecting the quality of language learning. Karahan (2007) considers that from the perspective of the learner, the factor 
affecting language learning can be mentioned as diverse needs and goals, peer groups, role models. From perspective of the learning process, the factors influencing language learning can be outlined as learning style and strategies, motivation and classroom interaction. On the other hand,

Kubanyiova (2006) states that the quality of learning engagement in the classroom does not depend on students' cognitive abilities alone, but it is also influenced by complex motivational and affective factors. It means that the quality of language teaching and learning process does not only involve some of elements, but also all of teaching and learning elements including teacher. In this case, teacher also has a big role to determine the quality of language teaching and learning process itself.

Brown (2001, p. 72) claims that

"One of more complicated problems of second language learning and teaching has been to define and apply the construct of motivation in the classroom". Motivation is significant determinant of success in learning a second or foreign language. "It can be defined as driving force that pushes someone to do something" (Astuti, 2013, p. 14). Without motivation, it seems to be impossible to achieve success in foreign language learning. "Motivation could be considered as the emotion that a person could have towards learning a foreign language, and it is determined by his/her predisposition and personality characteristics." (Karahan, 2007, p. 2). Therefore motivation is one of the most important in teaching foreign language especially English language.

The teacher plays an important role in motivating student especially in the foreign language classroom (Astuti, 2013, p. 14). The development of classroom engagement increases when the teacher has the ability to build students motivation in teaching and learning process. Ramirez (2010, p. 22) states "the teachers' ability to motivate is important because it creates a freestressed atmosphere and establishes a relationship of mutual confidence and motivation". From that statement, it is clear that a teacher, especially language teacher, should have ability to make a positive classroom atmosphere and good relation with students in classroom, because when all of classroom elements can support each other, it will build students motivation to learn confidently.

The importance of motivation in teaching and learning process makes teacher is aware that one of the roles that must be done in teaching process is as a motivator for students. Every teacher has a different way in motivating students; even what teachers done unconsciously in teaching and learning process, it could be a form of motivational strategies. Dornyei (2001) defines the term of motivational strategies as techniques that promote the individual's goal-related behavior. He also states that motivational strategies refer to those motivational influences that are consciously exerted to achieve some systematic and enduring positive effect. According to Wlodkowski (1999, p. 67), "Motivational strategies are deliberate instructor actions that enhance a person's motivation to learn". He also states that the strategy contributes to stimulating or creating a motivational condition: a mental/emotional state of being in which the learner is desirous of information, knowledge, insight and skill.

This research is underpinned by Motivational Strategies theory of Dornyei's (2001) who is identified motivational strategies into four phases, namely creating the basic motivational 
conditions, generating initial motivation, maintaining and protecting motivation, and encouraging positive retrospective self-evaluation. These phases are built on each other so that student's motivation is created, generated, maintained and encouraged (Dornyei, 2001, p. 29).

Dornyei (2001) classifies motivational strategies into four motivational phases namely creating the basic motivational conditions, generating initial motivation, maintaining and protecting motivation and encouraging positive retrospective self-evaluation. Creating the basic motivational conditions consist of three aspects, namely (1) Appropriate teachers behaviors to create a good relationship with students, (2) A pleasant and supportive classroom atmosphere, and (3) A cohesive learner group with appropriate group norms. On the other hand, generating initial motivation consists of five categories, namely (1) enhancing the learners' language sense and attitudes; (2) increasing the learners' expectancy of success; (3) increasing the learners' goal orientation; (4) making teaching material be relevant for the learners; (5) creating realistic learners' beliefs. Beside that, maintaining and protecting motivation consists of eight categories, namely (1) making learning stimulating and enjoyable, (2) presenting task in a motivating way, (3) setting specific learner goals, (4) protecting the learner self-esteem and increasing their confidence, (5) allowing learners to maintain a positive social image, (6) creating learners autonomy, (7) promoting self-motivating strategies and (8) promoting cooperation among the learners. Lastly, encouraging positive retrospective self-evaluation is divided into four categories, namely (1) promoting motivational attributions, (2) providing motivational feedback, (3) increasing learner satisfaction and (4) offering rewards and grades in a motivating manner.

Besides, attitude theory of Oskamp and Schultz (2005) is also used to identify the student's attitudes towards motivational strategies which are applied in EFL classroom through considering the three main aspects of attitudes, namely affective, behavioral, and cognitive.

The primary purpose of this research are to identify how teachers apply motivational strategies in teaching EFL, whether it is based on the phases of motivational strategies, whether these phase are applied sequentially, and whether all of these phases are applied, and to explore the students' attitudes towards motivational strategies which are applied in EFL classroom.

\section{METHOD}

This research applied a qualitative research to investigate a phenomenon. Denzin \& Lincoln (1995) state qualitative research involves an interpretive, naturalistic approach to its subject matter. This means that qualitative research studies things in their natural settings, attempting to make sense of, or interpret, phenomena in terms of the meanings people bring to them.

The research was undertaken in Junior High School 7 Kuningan. The participants were three English teachers of seventh grade and 123 seventh grade students in Junior High School 7

Kuningan, consisting of: 40 students of teacher 1, 41 students of teacher 2 , and 42 students of teacher 3 . These place, population and sample were chosen because researchers expected to identify how English teachers of seventh grade in Junior High School 7 Kuningan motivate students through applying motivational strategies in learning and teaching 
process. Besides, the researchers also aimed to explore the students' attitudes towards motivational strategies applied EFL classroom.

The instruments used were classroom observation, interview, and questionnaires. Classroom activity was observed through videoing the English teaching learning process conducted in the seventh grade to observe how teachers applied motivational strategies in teaching EFL and the students' attitudes toward motivational strategies applied in EFL classroom. The interview was conducted with three English teachers of seventh grade to explore whether they motivated their students in learning process, and how teachers applied motivational strategies in teaching EFL. Besides, the interview was also conducted with three students who were one representative of seventh grade students from each class to identify the students' attitudes towards motivational strategies applied in EFL classroom. The questionnaire was adapted from attitude theory and addressed to all of seventh grade students to explore the students' attitudes towards motivational strategies applied in EFL classroom. All of these data collection techniques were administered at the same time, which was on August 26 ${ }^{\text {th }}, 2015$ to September $4^{\text {th }}, 2015$.

\section{RESULTS}

Motivational Strategies Applied by Teacher 1 The result taken from classroom observation shows teacher 1 conducted all of four phases of motivational strategies. The teacher always tried to motivate students in teaching learning process.

In the first phase of motivational strategies; creating basic motivational condition, the teacher tried to create a good relationship with students by showing enthusiasm and cheerfulness to teaching, tried to make positive personal relationship with students by greeting students, remembering their names and smiling at them during teaching process, and the teacher also created a pleasant and supportive classroom atmosphere by bringing humors that was related to the material to make students feel comfortable and happy, and serious but relax. It can be strengthened by the result of interview that the teacher implied that in the first phase of motivational strategies, the teacher created an atmosphere to made students feel comfort to learn and providing humors which were related with the lesson itself so that students feel comfortable and happy, serious but relax. As mentioned by Dornyei (2001) that the humor is a tool to improve the classroom atmosphere.

Next, in the second phase of motivational strategies; generating initial motivation was conducted by the teacher through enhancing the learners' language sense and attitudes. The teacher encouraged the learners to apply English language proficiency in real life, but the teacher did not forget to notice students' understanding. Besides, the teacher also made the teaching material be relevant for the learners by relating the subject matter to the everyday experiences and backgrounds of students. The teacher explained something and gave examples based on students' real life. It was also strengthened by the result of interview that the teacher conveyed the material in the language style that was understood by students by considering the words selection and lesson and using some media like pictures and images to make students more interested in following the learning process in the classroom. The teacher also related the material to the 
real daily life. It is important to help students get the main point and benefits of the material learned. Teacher must know that one of the most demotivated factors for learners is when they have to learn something that they cannot see the point of because it has no seeming relevance whatsoever to their lives (McCombs and Whisler, 1997). Therefore, relating the material to the real daily life is one ways to motivate students in learning process.

The third phase of motivational strategies; maintaining and protecting motivation, was also conducted by the teacher through creating enjoyable learning by stimulating students to actively involve at class and selecting task which requires mental or bodily involvement from each participants. The teachers also tried to protect the learner self-esteem and improved their confidence by giving a persuasive expression of belief that students can have a good capability. "Self-esteem grows from the beliefs of others. When teachers believe in students, students believe in themselves. When those you respect think you can, you think you can" (Raffini, 1993, p. 147). Thus, teacher has an important role to help students believe in themselves. This was also found in the result of interview that the teacher implied that in the third phase of motivational strategies, the teacher gave an exercise to be done individually then discuss it together and also gave task in groups to help students convey opinions freely without fear of making mistakes.

Lastly, in the last phase of motivational strategies; encouraging positive retrospective self-evaluation, the teacher tried to provide motivational feedback by giving positive feedback and the teacher also appreciated student's work by responding all students' answer or opinion even they were wrong in order to make students not feeling down, after that, the teacher discussed the appropriate answers. It also found in the result of interview that the teacher said that in the last phase of motivational, the teacher tried to appreciate student's work by accepting students' answer or opinion even it was wrong to make students not feeling down, after that the teacher discussed it together and tell that what students said was less appropriate and tell students about the appropriate answers. The teacher must be able to give positive information feedback to students to make students understand about the mistake and how to correct it. "Most importantly, this feedback provides students with information rather than judgments against external standards or peer achievement." (Dornyei, 2001, p. 124). This is because judgment will make students felt down.

Motivational Strategies Applied by Teacher 2 The findings taken from classroom observation shows teacher 2 did not implement one of motivational strategies phases in teaching EFL. The teacher focused on the material, so the first thing to do when the teacher entered the classroom was delivering the material. The first phase of motivational strategies was not applied by the teacher. It also strengthened by the result of interview that the teacher did not apply motivational strategies sequential based on the phases of motivational strategies and the teacher did not implement the first phase of motivational strategies. The teacher said that the teacher explained the material after entered the classroom.

Dornyei (2001) said that motivational strategies cannot be employed successfully in a 'motivational vacuum'. It means that the teacher has to try to apply motivational strategies 
sequentially based on the phases from the first until the last phase because teaching is not only process of transfer knowledge but teacher has to know how to make the students' mind involve and ready to accept whole teaching and learning process. The teacher has to create a good precondition before any further attempts to generate effective motivation. One of the things that can be done by the teacher is to ommit the tension between the teacher and the students by looking at them with smiling or cheerful face. "Smiling at students is one of the things to convey personal attention". (Raffini, 1996, p. 182)

Next, the second phase of motivational strategies; generating initial motivation was conducted by the teacher through enhancing the learners' language sense and attitude. The teacher encouraged the learners to apply English language proficiency in real life, but the teacher did not forget to notice students' understanding. In this phase, the teacher also made the teaching material to be relevant for the learners by relating the subject matter to the everyday experiences and backgrounds of students. The teacher explained something and gave examples based on students' real life. It was also found in the result of interview that the teacher explained that in the second phase of motivational strategies, the teacher customized the media usage with the material to make teaching and learning process more interesting.

Furthermore, in the third phase of motivational strategies; maintaining and protecting motivation, the teacher made learning stimulating and enjoyable by breaking the monotony of learning. In this case, the teacher gave the task in pair work. From the result of interview, the teacher said that in the third phase of motivational strategies, the teacher gave tasks for students in groups or in pairs. Lastly, in the last phase of motivational strategies; encouraging positive retrospective self-evaluation, the teacher tried to provide motivational feedback by giving positive feedback, and then appreciated students' work by accepting students' answer or opinion even it was not appropriate. The teacher told students that what students said was less appropriate and told students about the appropriate answers. It was also found in the result of interview, in the last phase of motivational strategies; the teacher explained that the teacher tried to evaluate students positively, never convicted the students that 'this is wrong', but tell students that 'this is correct but still less complete and it should be more complete". The teacher must be able to give positive information feedback to students to make students understand about the mistake and how to correct it, giving a judgment just will make students felt down. "Most importantly, this feedback provides students with information rather than judgments against external standards or peer achievement". (Dornyei, 2001, p. 124)

\section{Motivational Strategies Applied by Teacher 3} The result of classroom observation shows teacher 3 conducted all of four phases of motivational strategies. The teacher always tried to motivate students in teaching learning process. It is important to motivate students because motivation is some kind of internal drive which pushes someone to do things in order to achieve something (Harmer, 2001). It can help to get success in learning process.

In the first phase of motivational strategies; creating basic motivational condition, when entering the classroom, 
the teacher tried to create a good relationship with students by showing cheerful face. The teacher also tried to make positive personal relationship with students by moving around in the class while teaching and learning process to convey personal attention to students. As mentioned by Raffini (1996) that moving around in class is one of small gesture that do not take much time which can convey personal attention and can touch the lives of every student in some way. It can be useful to make students feel motivated. However, the result taken from interview shows the teacher said that in the first phase of motivational strategies, the teacher created the conditions to make students motivated in learning English by giving some information of the purpose of learning English at first and tried to make students' mindset that English is easy and fun.

Next, in the second phase of motivational strategies; generating initial motivation was conducted by the teacher through enhancing the learners' language sense and attitudes. The teacher encouraged the learners to apply English language proficiency in real life, but the teacher did not forget to notice students' understanding. In this phase the teacher also made the teaching material to be relevant for the learners by relating the subject matter to the everyday experiences and background of students. The teacher explained the material and gave examples based on students' real life. In addition, the teacher tried to create realistic learners' beliefs. The teacher positively confronted the possible erroneous beliefs, expectations that learners may have by telling students about English generally. In addition, the result of interview shows the teacher just explained that the teacher covered material based on the type and covered with interesting media like pictures. Teacher can uses some kind of media or tool to make students interested to the material. Teacher also can uses classroom decoration as the media to cover the material. Dornyei (2001) says that the classroom decoration influences students' motivation such as putting posters, displaying bulletin board, etc.

In the third phase of motivational strategies; maintaining and protecting motivation, the teacher made learning enjoyable by breaking the monotony of learning channel of communication. The teacher gave the tasks to the students by using visual aids. In addition, the teacher also sets specific learners goals by telling students about the purposes of learning the materials and activities. It is important to do by the teacher in teaching and learning process because explain the purpose is a strategy to present task in motivating way (Dornyei, 2001). The result of interview shows the teacher said that in the third phase of motivational strategies, the teacher gave the task that was adapted to the material and what was given in the classroom. Before giving the tasks, the teachers always gave exercises then discussed them together, teacher also visited and communicated with students to identify whether students had any troubles or not. Lastly, in the last phase of motivational strategies; encouraging positive retrospective self-evaluation, the teacher tried to provide motivational feedback by giving positive feedback. And then, the teacher noticed and reacted to any positive contributions from students by taking time to give the thumbs up. Taking time to appreciate every student's contribution in teaching and learning process is useful to make students feel motivated. Teacher can use simple celebration way such as give the 
thumbs up and applause to appreciate every student's contribution. "A good rule of thumb is regardless of how small it, every success must be celebrated" (Scheidecker and Freeman, 1999, p. 106). It also strengthened by the result of interview that the teacher said that in the last phase of motivational, the teacher tried to evaluate the students mistakes positively, when the students worked on the task or exercise, the teachers do not blame or cut 'it is wrong or yes it's true' directly. However, at first, teachers gave students the opportunity to do the best and then discussed them together and asked the difficulty, so the teacher was able to give them more clearly and evaluate them from the beginning so that students could understand where their mistakes lied.

\section{Students' Attitudes towards Motivational Strategies Applied in EFL Classroom by Teacher 1.}

The result of questionnaires that was strengthened by the result of interview showed that most of students of teacher 1 showed positive attitudes in the terms of affective, cognitive, and behavioral towards motivational strategies that were applied by the teacher in EFL classroom.

In affective aspect, the students were pleased to follow English lesson (100\%), felt excited to heed the teacher teaching English lesson (100\%), interested in following English lessons because the teacher teaches the material in a fun way $(95 \%)$, even students did not prefer to do English task by own self than with friend (57.5\%). In behavioral asepct, the result showed that students were not hopeless if there are any difficulties in learning English (92.5\%) and always tried to do English task well and truly (85\%). In cognitive aspect, the result showed that students felt a loss if did not follow English lesson (85\%), learning continuously to make students' English skills are better than others $(97.5 \%)$, challenged if the teacher gives the quite difficult English task (85\%) and thought that should pay attention to the example given by the teacher first before do the English task (100\%). The overall result of questionnaire showed that students gave positive attitudes towards motivational strategies applied by teacher $1(88.25 \%)$.

It was also supported by the result of data taken from classroom observation which showed that students of teacher 1 showed positive attitudes toward motivational strategies applied by the teacher in EFL classroom. The students showed positive attitudes in affective, cognitive, and behavioral aspects. In affective aspect, the students were happy to follow English lesson, felt excited to heed the teacher teaching English lesson, interested in following English lessons, and students prefered doing English task with friend than by own self. In behavioral asepct, the result showed that students were not hopeless if there are any difficulties in learning English. It can be seen when students tried to ask the teacher about something which students did not understand. Next, in cognitive aspect, the result showed that students thought that should pay attention to the example given by the teacher first before doing the English task.

\section{Students' Attitudes towards Motivational Strategies Applied in EFL Classroom by Teacher 2. \\ The result taken from questionnaires showed the students gave posittive attitudes in affective, cognitive, and behavioral asepcts toward motivational strategies applied by the teacher 2 in EFL classroom.}


In affective aspect, the students were happy to follow English lesson (78.1\%), felt excited to heed the teacher teaching English lesson (78.8\%), interested in following English lessons because the teacher teaching the material in a fun way $(70.7 \%)$, but students did not prefer doing English task by own self than with friend $(78.1 \%)$. In behavioral aspect, the result showed that students were not hopeless if there are any difficulties in learning English (92.7\%) and always tried to do English task well and truly $(92.7 \%)$. In cognitive asepct, the result showed that students felt a loss if did not follow English lesson (63.8\%), learning continuously to make students' English skills are better than others $(97.6 \%)$, challenged if the teacher gives the quite difficult English task (85.4\%) and thought that should pay attention to the example given by the teacher first before do the English task (95.1\%). This indicated that students showed positive attitudes towards motivational strategies applied by teacher 2 (79.02\%). This was also in line with the result taken from interview.

However, the result taken from classroom observation showed the students showed less positive attitude towards the motivational strategies applied in EFL classroom by the teacher 2 . This was because, there were only a small part of students who actively participated in teaching and learning process. Besides, it also found that there were only a small part of students who felt happy to follow English lesson, felt excited to heed the teacher teaching English lesson and interested in following English lessons. On the other hand, related with cognitive asepct, athe result showed that students felt challenged if the teacher gives the quite difficult English task.

\section{Students' Attitudes towards Motivational Strategies Applied in EFL Classroom by Teacher 3}

The result of questionnaire that was supported by the result of interview showed that most of students of teacher 3 showed positive attitudes in affective, cognitive, and behavioral aspects towards motivational strategies applied in EFL classroom.

In affective aspect, students were happy to follow English lesson (100\%), felt excited to heed the teacher teaching English lesson (90.5\%), interested in following English lessons because the teacher teaching the material in a fun way $(83.3 \%)$, and students prefer doing English task by own self than with friend $(54.8 \%)$. In behavioral asepct, the result showed that students were not hopeless if there are any difficulties in learning English $(80.9 \%)$ and always try to do English task well and truly (90.8\%). In cognitive aspect, the result showed that students felt loss if did not follow English lesson (90.5\%), learning continuously to make students' English skills are better than others (83.3\%), challenged if the teacher gives the quite difficult English task (80.9\%) and thought that should pay attention to the example given by the teacher first before do the English task (100\%). From those results, It can be concluded that the students gave positive attitudes towards motivational strategies applied by teacher $3(85.71 \%)$.

It can be approved by the result of data from classroom observation which showed that students of teacher 3 gave positive attitudes toward motivational strategies applied in EFL classroom. In affective asepct, most students felt happy to follow English lesson, felt excited to heed the teacher teaching English lesson, interested in following English lessons. It can be seen when students gave attention 
to the teacher and participated actively in teaching learning process. In behavioral asepct, the result showed that students tried to do English task well and truly. In cognitive asepct, the result showed that students thought that should pay attention to the example given by the teacher first before do the English task.

\section{CONCLUSIONS}

Based on the findings taken from classroom observation, intervies, and questionnaires, it was found that teacher 1 and teacher 3 applied motivational strategies completely and sequentially based on the phases of motivational strategies. Both teachers tried to motivate students continuously in teaching EFL to make an effective teaching and learning process. That was responded positively by students of both teachers. Besides, It can be seen from the result of questionnaires from students of teacher 1 which was $88.25 \%$ and students of teacher 3 which was $85.71 \%$.

Furthermore, the result taken from the interview conducted with students of both teachers showed that the students showed positive attitudes towards motivational strategies that were applied by both teachers in EFL classroom.

On the other hand, teacher 2 did not apply motivational strategies completely and sequentially based on the phases of motivational strategies. The teacher missed the first phase of motivational strategies because the teacher focused on the material, so the first thing that was done by the teacher was delivering the material to the students. That was responded negatively by students. Students showed negative attitudes towards motivational strategies that were applied by the teacher in teaching EFL. From the result of classroom observation, it can be seen that students did not particiapte actively in teaching and learning process. Most students were passive during the teaching and learning process and only a small part of students which were active enough in the teaching and learning process. However, this was not in line with the result taken from questionnaire which indicates that students gave positive attitudes which was $79.02 \%$ and gave positive answer in the interview.

Those findings indicated that the way teachers applied motivational strategies in EFL classroom determined the students' attitudes towards motivational strategies applied in EFL classroom.

\section{REFERENCES}

Astuti, S. P. (2013). Teacher's and student's perception of motivational teaching strategies. TEFLIN Journal, 24 (2), 1431. Retrieved from http://www.journal.teflin.org (January 9th $2015,7: 43$ a.m.)

Broughton, G., Brumfit, C., Flavell, R., Hill, P. \& Pincas, A. (1980). Teaching English as foreign language ( $2^{\text {nd }}$ edition). London:University of London Institute of Education.

Brown, H. D. (1994). Principles of learning and teaching ( ${ }^{\text {rd }}$ edition). Englewood Cliffs, New Jersey: Prentice-Hall Regents.

Brown, H. D. (2001). Teaching by principles: An interactive approach to language pedagogy. New York: Addison Wesley Longman, Inc.

Brown, H. D. (2007). Teaching by Principles: An interactive approach to language pedagogy. New York: Addison Wesley Longman, Inc.

Cheng, H. F. (2007). The use of motivational strategies in Taiwanese English classroom. The Proceedings of 2007 International Conferences and Workshop of TEFL and Applied Linguistics, 153174. Taipei: Crane Publishing Co.

Creswell, J. W. (2009). Design qualitative, quantitative and mixed methods approaches (3 ${ }^{\text {rd }}$ edition). USA: Sage Publications Inc. 
Denzin, N. K. \& Lincoln, Y. S. (1995). Handbook of qualitative research. London: Sage Publications.

Dornyei, Z \& Csizer, K. (1998). “Ten commandments for motivating language learners": Result of an empirical study. Language Teaching Result 2, 203-219.

Dornyei, Z. (2001). Motivational strategies in language classroom. Cambridge: Cambridge University Press.

Eggen, P. D. \& Kauchak, D. P. (2001). Education psychology: Windows on classroom. Upper Saddle River, New Jersey: Merrill Prentice Hall.

Ellis, T. I. (1984). Motivating teachers for excellence. ERIC Clearinghouse on Educational Management: ERIC Digest, 6, 2-3. ERIC Document Reproduction Service, No: ED259449.

Fraenkel, J. R., \& Wallen, N. E., (2009). How to design and evaluate research in education (7th edition). New York: McGraw-Hill Higher Education.

Harmer, J. (1983). The practice of English language teaching. New York: Longman group.

Harmer, J. (2001). How to teach English : An introduction to the practice of English language teaching. England: Longman Press.

Harmer, J. (2001). The practice of English language teaching ( $3^{\text {rd }}$ edition). Longman: Pearson Education.

Karahan, F. (2007). Language attitude of Turkish students towards the English language and its use in Turkish context. Retrieved from http://jas.cankaya.edu.tr/jas7/07FIRDEFSKARAHAN.pdf. (at January $29^{\text {th }}, 2015,10: 23$ a.m.)

Kubanyiova, M. (2006). Developing a motivational teaching practice in EFL teachers in Slovakia. Challenges of promoting teacher change in EFL context, 10(2), 1-17. United Kingdom: University of Nottingham.

Latha, B. \& Ramesh, P. (2012). Teaching English as a second language: Factors affecting learners speaking skills. IJERT Journal, 1 (7), 1-6.
Latham, Andrew S. (1998). Teacher satisfaction. Educational Leadership, 55, 82-83.

Luthfiyah. (2011). Improving students motivation in learning speaking by using contextual teaching \& learning. Retrieved from http:/ / resopsitory.uinjkt.ac.id (at June 28, 2015, 10:55 a.m.)

McCombs, B. L. \& Whisler, J. S. (1997). The learner-centered classroom and school: Strategies for increasing students motivation and achievement. San Fransisco, CA: Jossey-Bass.

Nugroho, R. A. (2008). Motivational teaching strategies employed by English teachers in Yogyakarta. Retrieved from http:/ / www.ethesys.lib.mcu.edu.tw. (at January 23, 2015, 9:48 a.m.)

Oemar, H. (1995). Kurikulum dan pembelajaran. Jakarta: Bumi Aksara.

Olson, J. M. \& Maio, G. (2003). Attitudes in social behavior. New York: Wiley.

Oskamp, S. \& Schultz, P. W. (2005). Attitudes and opinion(3 ${ }^{\text {rd }}$ edition). New Jersey: Lawrence Erlbaum Associates.

Printrich, P. R. \& Howard, S. D. (1996). Motivation in education: Theory, research, and application .Ohio: Prentice-Hall.

Raffini, J. P. (1996). 150 ways to increase intrinsic motivation in the classroom. Needham Heights, MA: Allyn and Bacon.

Ramirez, A. C. V. (2010). Students' perception about the development of their oral skills in an English as foreign language teacher training program. Retrieved from http://www.researcharchive.edu.tw. (at January 03, 2015, 7:18 a.m.)

Ryan, R. M. \& Deci, E. L. (2000). Intrinsic and extrinsic motivations: Classic definitions and new directions. Contemporary Educational Psychology, 25, 54-67.

Ryan, R. M. \& Deci, E. L. (2000). Selfdetermination theory and the facilitation of intrinsic motivation. Social Development and Well-Being. American Psychologist, 55(1), 68-78. 
ENGLISH REVIEW: Journal of English Education Vol. 4, Issue 1, December 2015

Sakina, R. (2013). An analysis of anomalous exchange in young learners classroom interaction. Retrieved from http:// resopsitory.upi.edu.

Scheidecker, D. \& Freeman, W. (1999). Bringing out the best in students: How legendary teachers motivate kids. Thousand Oaks, CA: Corwin Press.

Shuttleworth, M. Case Study Research Design. Retrieved from https://explorable.com/case-studyreearch-design. (at March 01, 2015, 8:43 a.m.)

Stone, D. R. \& Elwin, C. N. (1987). Educational psychology. Oxford: Oxford University Press.
ISSN 2301-7554

https://journal.uniku.ac.id/index.php/ERJEE

Subana, R. R. \& Sudrajat, M. (2000). Statistik pendidikan. Bandung: Pustaka Setia.

Suherdi, D. (2008). Mikroskoppedagogik: Alat analisis proses belajar mengajar. Bandung: UPI Press.

Ur, P. (1996). A course in language teaching: Practice and theory, New York: Cambridge University Press.

Williams, M., \& Robert L. B. (1997). Psychology for language teachers: A social constructivist approach. Cambridge:Cambridge University Press.

Wlodkowski, R. J. (1999). Enhancing adult motivation to learn. San Fransisco: Jossey-Bass. 